Abstracta Iranica Abstracta Iranica

Revue bibliographique pour le domaine irano-aryen

Volume 24 | 2003

Comptes rendus des publications de 2001

« Fifth Century Nippur: Texts of the Murasus and from their Surroundings ». JCS 53, (2001), pp. 83-132.

Rémy Boucharlat

(2) OpenEdition

Journals

Édition électronique

URL : http://journals.openedition.org/abstractairanica/34339

ISSN : 1961-960X

Éditeur :

CNRS (UMR 7528 Mondes iraniens et indiens), Éditions de l'IFRI

Édition imprimée

Date de publication : 15 mai 2003

ISSN : 0240-8910

Référence électronique

Rémy Boucharlat, « «Fifth Century Nippur : Texts of the Murasus and from their Surroundings ». JCS 53, (2001), pp. 83-132. », Abstracta Iranica [En ligne], Volume 24 | 2003, document 79, mis en ligne le 05 janvier 2010, consulté le 25 septembre 2020. URL : http://journals.openedition.org/ abstractairanica/34339

Ce document a été généré automatiquement le 25 septembre 2020.

Tous droits réservés 


\section{« Fifth Century Nippur : Texts of the Murasus and from their Surroundings ».JCS 53, (2001), pp. 83-132.}

\section{Rémy Boucharlat}

De cette archive célèbre (plus de 740 tablettes et fragments) trouvée, il y a plus d'un siècle et dispersée dans plusieurs musées, l'A., après d'autres, a déjà donné plusieurs études. Celle qu'il ajoute ici pour quatre tablettes confirme l'importance de cette documentation pour contribuer à l'histoire de l'économie que pratiquaient institutions et populations locales dans une satrapie de l'empire. Aux textes eux-mêmes s'ajoutent des empreintes de sceaux qui sont également une riche source d'information.

\section{INDEX}

Thèmes : 3.2.2. Pré-Achéménides et Achéménides

\section{AUTEURS}

RÉMY BOUCHARLAT

CNRS - Lyon 